\title{
A NEW RECORD OF A LESSEPSIAN FISH, LAGOCEPHALUS SUEZENSIS (ACTINOPTERYGII: TETRAODONTIFORMES: TETRAODONTIDAE), IN THE SOUTH MEDITERRANEAN (LIBYAN COAST)
}

\author{
Abdallah BEN-ABDALLAH ${ }^{1}$, Akram AL-TURKY ${ }^{2}$, \\ Ahmed NAFTI ${ }^{2}$, and Esmail SHAKMAN ${ }^{1 *}$ \\ ${ }^{1}$ Zoology Department, Alfateh University, Libya \\ ${ }^{2}$ Marine Biology Research Center, Libya
}
Ben-Abdallah A., Al-Turky A., Nafti A., Shakman E. 2011. A new record of a Lessepsian fish, Lagocephalus suezensis (Actinopterygii: Tetraodontiformes: Tetraodontidae), in the south Mediterranean (Libyan coast). Acta Ichthyol. Piscat. 41 (1): 71-72.

Abstract. The Lessepsian invasive fish, Lagocephalus suezensis was recorded for the first time in the eastern part of the Libyan coast, adding a new invasive species to the 16 Lessepsian species recorded in the Libyan waters.

Keywords: Lessepsian migration, Lagocephalus suezensis, Libya

Libya is located in the south Mediterranean with about $2000 \mathrm{~km}$ coast line, which is characterized by a diverse topography and wide range of habitats. Since the opening of the Suez Canal, between the Red Sea and the Mediterranean in 1869 , a total of 309 species, called "Lessepsian" species, entered into the Mediterranean waters, including ca. 77 fish species (Golani 2010). To date, 22 invasive fish species have been recorded from the Libyan coast (Ben Abdallah et al. 2010), out of which 16 are Lessepsian (Shakman and Kinzelbach 2006, 2007a, 2007b).

Lagocephalus suezensis Clark et Gohar, 1953 is a Lessepsian migrant that lives on the benthic sandy and muddy habitat down to the depth of $40 \mathrm{~m}$. It feeds on benthic invertebrates, spawns in the summer, and its eggs and larvae are planktonic. The first record of this species was in 1977 from the Lebanon coast (Mouneimné 1977). Since then its distribution expanded to other parts of the Mediterranean (Israeli coast: Golani 1996, Syrian coast: Saad 2005, Rhodes Island: Corsini et al. 2005).

The presently reported record is based on a single specimen captured off the eastern section of the Libyan coast (Tobruk), with a trammel net (inner mesh $26 \mathrm{~mm}$, outer mesh $120 \mathrm{~mm}$ ) on a rocky bottom covered with algae at the depth of about $30 \mathrm{~m}$. The specimen was washed with fresh water immediately after identification, and photographed (Fig. 1). Prior to preservation in formaldehyde $(5 \%)$, its morphometric and meristic characteristics were determined (Table 1). The specimen was deposited in the Marine Biology Research Center Museum, Tajura, Libya, receiving the number MBRC, F147. L. suezensis was

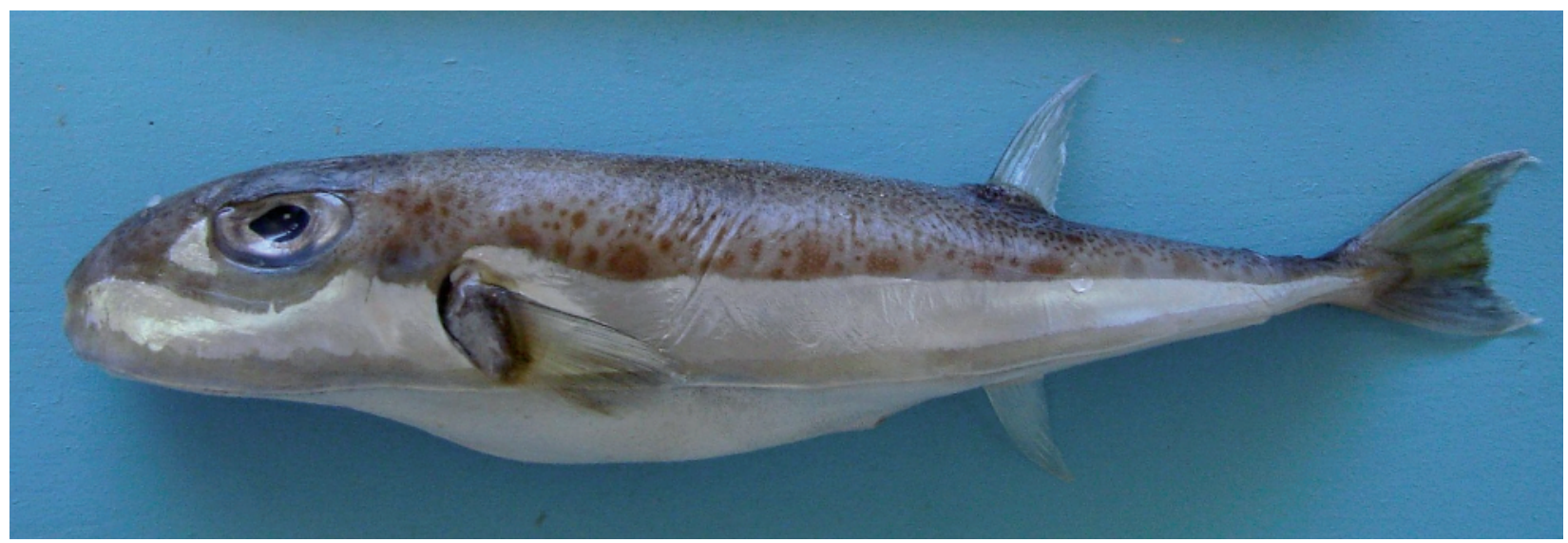

Fig. 1. Lagocephalus suezensis from the Libyan coast

\footnotetext{
${ }^{*}$ Correspondence: Dr. Esmail Shakman, Zoology Department, Alfateh University, Libya, phone: (+218) 922761703, e-mail: shugmanism@yahoo.com.
} 
Table 1 the Mediterranean, and six more fish records from Rhodes.

Morphometric and meristic characteristics of the Lagocephalus suezensis from Libyan coast

\begin{tabular}{|c|c|c|}
\hline & Character & Value \\
\hline \multirow{11}{*}{ 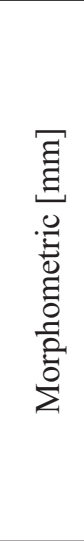 } & Total length & 190 \\
\hline & Fork length & 183 \\
\hline & Standard length & 165 \\
\hline & Head length & 49 \\
\hline & Eye diameter & 11,18 \\
\hline & Pre-orbital & 23 \\
\hline & Post-orbital & 14 \\
\hline & Pre-dorsal & 115 \\
\hline & Pre-anal & 115 \\
\hline & Base of dorsal fin & 9 \\
\hline & Base of anal fin & 8 \\
\hline \multirow{4}{*}{ 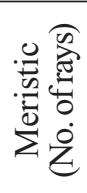 } & Dorsal fin & 10 \\
\hline & Anal fin & 9 \\
\hline & Pectoral fin & 15 \\
\hline & Pelvic fin & $\mathrm{I}+5$ \\
\hline
\end{tabular}

caught together with other fish, namely Oblada melanura, Diplodus sargus, D. vulgaris, Siganus luridus, S. rivulatus, Sparus aurata, Labrus viridis, and Sparisoma cretense in coastal waters, showing that most the Lessepsian fish species live in the coastal water (Por 1978). This species is added to the sixteen Lessepsian fish species previously recorded in Libyan waters (Shakman and Kinzelbach 2007a).

\section{REFERENCES}

Corsini M., Margies P., Kondilatos G., Economidis P.S. 2005. Lessepsian migration of fishes to the Aegean Sea: First record of Tylerius spinosissimus (Tetraodontidae) from Cybium 29 (4): 347-354.

Golani D. 1996. The marine ichthyofauna of the eastern Levant-history, inventory and characterization. Israel Journal of Zoology 42: 15-55.

Golani D. 2010. Colonization of the Mediterranean by Red Sea fishes via the Suez Canal-Lessepsian migration. Pp. 145-188. In: Golani D., Appelbaum-Golani B. (eds.) Fish invasions of the Mediterranean Sea: Change and renewal. Pensoft, Sofia.

Golani D., Orsi-Relini L., Massuti E., Quignard J.P. 2002. CIESM Atlas of Exotic species in the Mediterranean. Vol. 1. Fishes. CIESM Publishers, Monaco.

Mouneimné N. 1977. Liste des poissons de la côte du Liban (Méditerranée orientale). Cybium 1: 37-66.

Por F.D. 1978. Lessepsian migration. Ecological Studies Vol. 23. Springer-Verlag, Berlin-Heidelberg-New York.

Saad A. 2005. Check-list of bony fish collected from the coast of Syria. Turkish Journal of Fisheries and Aquatic Sciences 5: 99-106.

Shakman E.A., Kinzelbach R. 2006. Halfbeak fish Hemiramphus far (Forsskål, 1775) in coastal waters of Libya. Zoology in the Middle East (Heidelberg) 39: 111-112.

Shakman E.A., Kinzelbach R. 2007a. Distribution and characterization of Lessepsian migrant fishes along the coast of Libya. Acta Ichthyologica et Piscatoria 37 (1): 7-15.

Shakman E.A., Kinzelbach R. 2007b. Commercial fishery and fish species composition in coastal waters of Libya. Rostocker Meeresbiologische Beiträge 18: 65-80.

Received: 22 February 2010

Accepted: 13 September 2010 Published electronically: 25 March 2011 